\title{
O APOLÍNEO E O DIONISÍACO NA ORIGEM DA TRAGÉDIA DE NIETZSCHE
}

Jean Carlos Cavalcante Novo ${ }^{1}$

Resumo: O presente trabalho busca desenvolver uma compreensão a respeito do conceito de trágico presente na obra de Friedrich Nietzsche, a partir de uma análise de $O$ Nascimento da Tragédia. Discutimos as características da estética nietzschiana pensando o trágico utilizando as imagens poéticas de Apolo e Dioniso. Dessa forma o pensamento trágico aparece para Nietzsche como alternativa à metafísica tradicional e ao pessimismo de Schopenhauer. Nietzsche propõe uma reabilitação da arte e da vida pela retomada do movimento originário do devir.

Palavras-chave: Trágico; Apolo; Dioniso.

\begin{abstract}
This paper attempts to present an understanding of the concept of tragic in Friedrich Nietzsche's work, based on an analysis of The Birth of Tragedy. We discuss the characteristics of nietzschian aesthetics considering the tragic as the poetic images of Apollo and Dionysus. Thus tragic thought appears to Nietzsche as an alternative to traditional metaphysics and Schopenhauer's pessimism. Nietzsche proposes a rehabilitation of art and life by resuming the proper movement of becoming.
\end{abstract}

Keywords: Tragic; Apollo; Dionysus. 
Elaboramos uma exposição dos principais elementos que, de acordo com Nietzsche em O Nascimento da Tragédia, originam o trágico como o resultado da luta e tensão entre impulsos artísticos em expressa oposição. Nossa leitura procura demonstrar que o jovem Nietzsche ao pensar o trágico propõe uma reinterpretação dos gregos adotando como paradigma aquilo que a arte trágica é capaz de comunicar. A partir desta visão trágica do mundo Nietzsche pretende reavaliar o papel da filosofia e dos demais empreendimentos que ela dá ensejo: a filologia e demais ciências positivas - como possibilidades abertas pela intromissão do elemento teórico que desencadeia a metafísica do ocidente.

De acordo com Roberto Machado, O Nascimento da Tragédia tem dois objetivos principais: a crítica da racionalidade conceitual instaurada na filosofia por Sócrates e Platão e a apresentação da arte trágica, expressão das pulsões artísticas dionisíaca e apolínea como alternativa à racionalidade. ${ }^{2}$ Nossos esforços se concentram nesse segundo núcleo de discussão, procurando enfatizar o papel determinante do coro trágico nos desenvolvimentos sucessivos do polemos entre Apolo e Dioniso como harmonia que produz movimento, devir. Com isso, o ingresso de Nietzsche nas discussões filosóficas começa com a problematização da filosofia. A filosofia é posta em questão a partir de sua pergunta fundamental sobre a essência do ente. Afirmar que Nietzsche pensa a verdade e a essência do ente em seu ser causa certo estranhamento: não é Nietzsche o filósofo cujos escritos se preocupam preponderantemente em desmistificar esses conceitos? Certamente. Pois no pensamento nietzschiano verdade e essência em hipótese alguma podem ser compreendidas com referência aos conceitos de unidade e identidade. Para o jovem Nietzsche a verdade como a essência do ente é a vontade que se mostra de modo exemplar na arte trágica. O trágico: uma solução diferente à pergunta sobre a essência do ente. Em $O$ Nascimento da Tragédia Nietzsche se preocupa inicialmente com a exposição da origem da arte trágica, que se consolida como um modo privilegiado de nos relacionarmos com as coisas e a existência.

Para responder à pergunta "que é o trágico?" Nietzsche dedica, principalmente, os primeiros dez parágrafos do livro. Nossa leitura interpretativa dialoga em alguns momentos com escritos de maturidade e fragmentos póstumos, com o intuito de argumentar que nas publicações de juventude do filósofo se desenvolveram os problemas e as premissas sobre as quais o seu pensamento posterior se norteia, de modo que questões presentes no Nascimento da

${ }^{2}$ MACHADO. 2011. p, 11 
Tragédia serão retomadas por Nietzsche em diversos momentos de sua obra. Mas o que Nietzsche pensa propriamente sobre a tragédia e qual a sua origem?

Teremos ganho muito a favor da ciência estética se chegarmos não apenas à intelecção lógica mas à certeza imediata da introvisão [Anschaunng] de que o contínuo desenvolvimento da arte está ligado à duplicidade do apolíneo e do dionisíaco,da mesma maneira como a procriação depende da dualidade dos sexos, em que a luta é incessante e onde intervêm periódicas reconciliações.( NIETZSCHE. 2007, p. 24).

Nietzsche inicia com a exposição de sua tese a respeito da origem da tragédia: Para o filósofo ela resulta de um emparelhamento ou periódica reconciliação entre dois impulsos naturais. A tese é polêmica em diversos sentidos. Herdamos da tradição a noção de que entre arte e natureza existe uma contrariedade correspondente à oposição entre liberdade e necessidade. A arte é o âmbito onde o cálculo e as determinações do conceito e da causalidade não impõem seu domínio e controle. Nos diversos momentos da experiência estética, seja na sua produção como na contemplação de obras de arte abandonamos as amarras da regra e do que é regrado. A arte, nesse sentido, está em conformidade com a liberdade, e por isso os impulsos que originam o trágico não poderiam se referir justamente ao natural pensado enquanto a res extensa, que opera mecanicamente, alheio às exigências e necessidades da razão. A natureza se for pensada como conformidade a leis e representação da necessidade, que não pode se dizer bela por não ser livre, na medida em que é vista como oposição e contrariedade a uma subjetividade, não pode ser origem da arte.

Nietzsche pensa a tragédia como modelo para uma posição ontológica capaz de rivalizar com o modelo "racionalista" delimitado pela primazia do elemento teórico-conceitual, o filósofo pensa a natureza como origem da arte como caminho para a superação dessa dicotomia, e interpreta a natureza enquanto essência do ser. Para Nietzsche, natureza não é uma região do ente, um objeto ou recorte do real que é privilegiado em detrimento de outro; natureza aparece com o sentido de vigência do real como tal, do princípio interno das coisas.

O desenvolvimento da arte é similar à procriação, esta é garantia da manutenção de uma espécie animal, assim como a dualidade entre Apolo e Dionísio é "procriativa” na medida em que estabelece a tensão interna que constitui a unidade da natureza do real. Por isso Nietzsche chama atenção para as vantagens da certeza imediata da introvisão em detrimento da lógica como um ganho positivo a favor da ciência estética. Pois a intromissão da lógica, como condição para uma abordagem cientifica, implica reduzir a arte a um objeto do saber 
especializado. Uma estética pensada em parâmetros científicos é consequência da perda da vitalidade artística. Nietzsche parte da posição que admite a forma artística em expressa oposição ao pensamento, acredita que este é forçado a destruí-la quando atua segundo seu modo. Por isso Nietzsche não pode levar adiante uma estética sistemática como fazem seus adversários, pois isso significaria concordar que a arte foi superada, que esta é incapaz de atender as necessidades do homem em uma época marcada pelo pensamento considerado meio e finalidade em si mesmo. Uma abordagem científica sempre contrapõe o objeto investigado a uma substância fundamental, Nietzsche por outro lado procura interpretar a arte como a possibilidade de inversão desse processo de domínio e controle da vida por meio do conceito.

Stegmaier, numa leitura de Humano, Demasiado Humano, compreende que a estética em Nietzsche se desenvolve

\begin{abstract}
A partir de conceitos das artes plásticas, sob a forma de uma "apresentação incompleta, como em relevo", acreditando que uma tal apresentação pode ser mais "eficaz" do que um "acabamento minucioso: deixa-se um trabalho maior para quem observa, incitando-o a continuar a elaboração do que se destaca diante de seus olhos em intensa luz e sombra, a pensá-la até o fim e superar ele mesmo o obstáculo que o impedia até então o seu desprendimento completo". (STEGMAIER, W. 2013.p, 231).
\end{abstract}

Para Nietzsche, a ciência estética deve se orientar por uma certeza íntima, ou seja, deve mediar a sua própria compreensão. O que significa que a estratégia adotada pelo filósofo consiste em solapar a importância do conceito recorrendo às imagens dos deuses Apolo e Dioniso como uma forma de linguagem que, sendo mais afim às questões da arte, torna-se mais significativa que o conceito: "Nós falamos de poesia de um modo tão abstrato por que todos nós costumamos ser maus poetas." ${ }^{\prime 3}$. Falar abstratamente é retirar a arte do horizonte sensível que lhe é próprio. A partir de então, a analogia com a procriação, relativa a um instinto sexual adquire contornos mais precisos: se a justificação última de um conceito se dá no âmbito da pura abstração, este não pode figurar como critério para as questões da arte. Para Nietzsche, a arte diz respeito à vida entendida enquanto impulso, pulsão. De acordo com Heidegger, Nietzsche não pergunta sobre a tragédia para descrevê-la como um fenômeno ou como expressão da cultura, mas quer mostrar por meio da arte trágica e da caracterização de sua

${ }^{3}$ NIETZSCHE. 2007, p.56 
essência o que é vontade ${ }^{4}$, a verdadeira essência da arte é conduzida ao trágico e o trágico consiste na fórmula originária da experiência do ser em Nietzsche.

Os deuses gregos, na perfeição com que os encontramos já em Homero, não devem ser concebidos como rebentos da falta (Not) e da necessidade: tais entidades não foram inventadas certamente pela mente (Gemut) abalada pela angústia: não foi para voltar às costas à vida que uma genial fantasia projetou suas imagens no azul. A partir delas fala uma religião da vida, não do dever, da ascese ou da espiritualidade. Todas estas figuras respiram o triunfo da existência, um profuso sentimento de vida acompanha o seu culto. (NIETZSCHE. 2010, p. 15).

Como ressalta Stegmaier ${ }^{5}$, necessidade é um conceito condutor na obra de Nietzsche. O filósofo utiliza o termo na forma adjetiva e substantiva, a maior parte das vezes no plural, indicando "sofrimentos", "desejos", sempre em oposição aos "conceitos gerais" que supõem uma falsa realização da ação que, na forma verbal aponta para o fazer como inesgotável. Da necessidade desenvolve-se um pensamento capaz de experimentá-la, enfraquecê-la tendo em vista a sua superação. As necessidades obrigam a nos libertarmos delas, diminuindo a nossa carência de disciplina e totalização. Nesse sentido a arte, sob a imagem dos deuses gregos não representam o refúgio diante da necessidade aterradora que aflige o homem por meio da postulação de uma realidade fantasiosa. O filósofo chama atenção para o caráter afirmativo desse "ato da vontade helênica". Entre os gregos não observamos uma religião do tipo que alimenta a esperança no transmundano, a religião da vida não é um esforço de aproximação de um modelo ideal. Ela não pretende dizer o que algo é e por isso prescinde do conceito, também não é necessário "viver com ela" daí não prescrever deveres e não pretender elevar o homem além de si por meio de uma postura ascética.

As figuras míticas não despertam o desejo de negação daquilo que é, elas não postulam estágios paradisíacos. Ao invés disso, elas respiram o triunfo da existência, a vitória do homem sobre si mesmo que é reconduzido ao seu fazer metafísico propriamente dito. Essa observação contundente nos alerta para a necessidade de nos desvencilharmos dos estigmas religiosos que a experiência monoteísta imprimiu no Ocidente e atentarmos para o elemento poético que representam as figuras de Apolo e Dioniso. Não devemos pensá-los como entidades ou seres existentes; é na condição de fantasia genial, de impulsos artístico-criadores que ambos dão origem à obra de arte.

\footnotetext{
${ }^{4}$ HEIDEGGER. 2010, p.71

${ }^{5}$ STEGMAIER, W. 2013, p. 257.
} 
A seus dois deuses da arte, Apolo e Dioníso, vincula-se a nossa cognição de que no mundo helênico existe uma enorme contraposição, quanto a origens e objetivos, entre a arte do figurador Plástico [Bildner], a apolínea, e a arte não figurada [unbildlichen] da música, a de Dioníso: ambos os impulsos, tão diversos, caminham lado a lado, na maioria das vezes em discórdia aberta e incitando-se mutuamente a produções sempre novas, para perpetuar nelas a luta daquela contraposição sobre a qual a palavra comum "arte" lançava apenas aparentemente a ponte; até que por fim, através de um ato metafísico da vontade helênica, apareceram emparelhados um com o outro, e nesse emparelhamento tanto a obra de arte dionisíaca quanto a apolínea geraram a tragédia ática. (NIETZSCHE. 2007, p.24).

Na tragédia Dioniso fala a linguagem de Apolo, essa fala não se submete às engrenagens da representação, a arte é uma palavra comum para o jogo entre impulsos naturais e independentes cuja oposição incide nas belas artes e pode ser observada como o conflito de origem e propósito das artes figuradas, como a escultura, e não figuradas, como a música. A música tem esse destaque como um tipo de arte que não exige erudição da parte do espectador para o seu usufruto, como indício de que, para Nietzsche, a consciência pensante não pode ser a origem da criação artística. Como ponte aparente aponta para o caráter deveniente da arte. $\mathrm{O}$ substantivo comum "arte" acompanha a ideia de uma generalidade específica, induz pensar que diante dos variados tipos de arte e multiplicidade de obras de arte existe uma identidade comum que aponta para uma unidade essencial. Para Nietzsche não há tal unidade, a arte se constitui exatamente pelo elemento contraditório. Veremos que o trágico como reconciliação que aparece logo de saída no texto não significa a redução de um aspecto a outro por meio de uma interação causal. Apolo e Dioniso vivem de sua contradição e na tragédia grega essa contradição se mostra de modo exemplar como obra de arte, eles aparecem conjugados, de mãos dadas.

Quando esses dois impulsos rivais aparecem juntos pela primeira vez, e o predomínio de um sobre outro se mostra tênue, a vontade os obriga a mostrarem-se numa unidade que acolhe em si a contradição nos pondo diante da harmonia do que tende a se opor. A tese inicial de Nietzsche estabelece o devir como princípio regulador da arte e a recusa do que é assegurado, perfeito e fixo.

Para nos aproximarmos mais desses dois impulsos, pensemo-los primeiro como os universos artísticos, separados entre si, do sonho e da embriaguez, entre cujas manifestações fisiológicas cabe observar uma contraposição correspondente à que se apresenta entre o apolíneo e o dionisíaco. (NIETZSCHE. 2007. p,24). 
Os sentimentos trágicos do sonho e da embriaguez constituem o modo de ser fundamental de nossa existência, por meio do qual e através do qual já sempre somos alçados para além de nós mesmos em direção ao devir que constitui a vontade. A vontade no homem se mostra primeiramente como afeto no corpo. Corpo entendido enquanto o imediatamente experimentado como desejo. Nietzsche em nenhum momento compreende o corpo como estrutura representacional, como objeto submetido às variações de tempo e espaço.

Para que possamos compreender o comportamento desses impulsos artísticos em seu movimento criador, examinaremos seus efeitos fisiológicos separadamente como se manifestam no gênero humano, sob os afetos do sonho e da embriaguez. A partir de seus mundos distintos procuraremos articulá-los mostrando como esses aspectos dão origem à tragédia ática.

Sonho e embriaguez despertam o sentimento de delícia em relação à existência ${ }^{6}$, constituem instintos necessários para a apreensão intuitiva da vida enquanto vontade. De acordo com Rosa Dias ${ }^{7}$, a distinção entre sonho e embriaguez se apoia na oposição entre coisa-em-si e fenômeno e Nietzsche concebe essa estrutura em referência à filosofia de Schopenhauer marcada pela disjunção entre vontade e representação. Para Schopenhauer, atingimos o juízo filosófico quando adquirimos o conhecimento abstrato e refletido de que o mundo e as coisas que se dão conjuntamente nele são representações, imagens duma realidade que se oculta sob o véu do princípio de individuação.

Numa interpretação kantiana, isso significa: toda experiência possível tem como condição de possibilidade o sujeito que conhece, não havendo conhecimento do objeto fora da referência ao sujeito. Não conhecemos o sol a não ser um olho que vê o sol. O olho não explica o sol, não é causa do sol, não o produz, mas na medida em que o sol se apresenta primeiramente como intuição, ele é submetido às formas da sensibilidade que estão dadas a priori no sujeito transcendental. Para Schopenhauer o grande mérito da filosofia de seu tempo foi ter atingido esse ponto de partida comum e relacioná-lo ao problema da relação do ideal com o real para o âmbito da liberdade moral, ou seja, estabelecer um pressuposto comum aos questionamentos filosóficos.

Compreender o mundo como representação significa estabelecer uma dualidade entre sujeito e objeto. Ambos são necessários e inseparáveis em sua relação, porém diferentes. Somos

\footnotetext{
${ }^{6}$ NIETZSCHE. 2010. p, 5

${ }^{7}$ DIAS, R. M. 1997, p. 07-21
} 
sujeito na medida em que conhecemos o objeto e nos desconhecemos enquanto fenômeno singular, enquanto objeto entre os objetos. O sujeito não é cada um de nós, embora a individuação, sob o caráter da corporeidade, seja indispensável ao ato de representar.

Se alguma verdade pode ser expressa a priori, é essa, pois é uma asserção da forma de toda experiência possível e imaginável, mais universal que qualquer outra, que tempo, que espaço e causalidade, pois todas essas já a pressupõem; e se cada uma dessas formas, conhecidas por todos nós como figuras particulares do princípio de razão, somente vale para uma classe específica de representações, a divisão sujeito e objeto, ao contrário, é a forma comum de todas as classes, unicamente sob a qual é possível pensar qualquer tipo de representação, abstrata ou intuitiva, pura ou empírica. Verdade alguma é, portanto, mais certa, mais independente de todas as outras que esta: o que existe para o conhecimento, portanto o mundo inteiro, é tão-somente objeto em relação ao sujeito, intuição de quem intui, numa palavra, representação.( SCHOPENHAUER, 2005, p. 43).

Espaço, tempo e causalidade, formas da intuição e do entendimento, só podem valer para todo objeto na medida em que fazem referência ao sujeito. Não se trata de predicados pertencentes a este ou aquele objeto. Quando representamos o objeto conhecemos o sujeito, mas isso não significa que o objeto seja ilusório, fruto de uma suposta arbitrariedade do indivíduo que representa: o sujeito estabelece a forma de todo o objeto, não o seu conteúdo. Tanto é que, para Schopenhauer, objetos e representações coincidem. O mundo cerebral, do indivíduo epistêmico, e o mundo das coisas se identificam na referência ao sujeito que aparece como suporte do mundo. O suporte do mundo não é causa do mundo. Em diversos momentos Schopenhauer chama atenção para os limites do princípio de causalidade, que diz respeito exclusivamente a relações entre fenômenos.

O encadeamento causal nos fornece as regras da aparição de um fenômeno no espaço e no tempo, mas não explica, por exemplo, na mecânica, a origem da matéria ou da gravidade, que compreendidas como forças, não tem sua causa indicada. Do ponto de vista científico, isso se dá em proveito da ciência. $\mathrm{O}$ princípio de causalidade, estando submetido à referência ao sujeito nos permite constatar a sua validade para o âmbito fenomênico tanto $a$ priori, quanto $a$ posteriori. Por outro lado, indica que em todo fazer científico subjaz uma dependência metafísica, pensada enquanto o saber que compreende o conjunto total da experiência. A circunscrição dos limites da causalidade, na perspectiva de Schopenhauer, é o que nos põe diante do enigma do mundo e permite o espanto diante das coisas habituais e cotidianas. Se o princípio de individuação nos põe diante do encadeamento causal que ordena os fenômenos nos permitindo estabelecer leis eternas e imutáveis a seu respeito, revela também o seu aspecto 
negativo: a singularidade nos impõe a condição de fenômeno, o que implica uma vida nas cercanias da morte, orientada desde a condição finita de toda existência.

O princípio de individuação não dá conta de abarcar o todo da realidade. Isso que para Schopenhauer era motivo de desespero e terror é celebrado por Nietzsche com júbilo e alegria. A partir disso se evidencia a visão pessimista de Schopenhauer, como medo da aparência, uma "raivosa, vingativa aversão à vida" que se expressa como a vontade de liquidar a aparência por meio da redução a um princípio de identidade, procedimento comum à tradição metafísica que Nietzsche se opõe. Na filosofia de Nietzsche falta "a contraposição entre um mundo verdadeiro e um mundo aparente: há apenas um único mundo e este é falso, cruel, contraditório, sedutor, sem sentido..."8

O pensamento teórico-conceitual que se desenvolve com a metafísica nos põe diante do enigma como aquilo de que queremos escapar. Enigma é tudo aquilo que insiste em permanecer incomunicável, que recusa a se submeter à clareza da exposição dialógica. $\mathrm{O}$ enigma não nomeia coisa alguma, é o não dito incondicionado como condição de possibilidade de todo o dizer que se evidencia no momento em que a vida se mostra como resistência ao domínio e controle das determinações do sujeito. Queremos escapar ao enigma, para isso estabelecemos a verdade como meta. O enigma é espantoso, um monstro devorador que nos faz recuar diante da penetração na irrealidade do verdadeiro, a partir da identificação da vida como movimento contínuo de geração a partir da autodiferenciação de si, que nos faz ver o fluxo presente naquilo que se apresentou como um conjunto fixo e coerente de qualidades.

No poema intitulado Primeiro Fausto, Fernando Pessoa narra a saga da pequena razão humana, desde seu principiar como rejeição do movimento de autodiferenciação e sua superação a partir da redescoberta do devir seminal sob a figura do amor. Amor se refere ao páthos e diz respeito ao reestabelecimento e afirmação da tensão originária da existência. Vejamos os quatro versos do primeiro tema, titulado "O mistério do mundo":

Quero fugir ao mistério

Para onde fugirei?

Ele é a vida e a morte

Ó Dor, aonde me irei?

${ }^{8}$ NIETZSCHE. 2008. p. 426 
Na poesia de Fernando Pessoa a vida aparece como mistério, mistério é uma palavra para dizer a unidade entre a vida e a morte, pensada como relação de luta e tensão entre princípios ou forças que se conservam na diferença. A fuga ao mistério é simultaneamente o esforço de negar a vida em sua vitalidade, que postula a primazia da ideia, como a recusa do sem porquê. Observamos o desespero da vida, o sentimento de abandono diante do imponderável, o horror à existência que por não encontrar refúgio e na incapacidade de suportála assume a vontade de negação como o paradigma regulador que impulsiona todo o fazer teórico. A adoção dessa medida resulta na rejeição da visão de mundo trágica e desencadeia a tradição metafísica. Para o poeta está em jogo o poder dizer diferente, a criação artística como reprodução do inaugural. Os seis versos da décima estrofe tornam visível a vida como infinita potência criadora:

O segredo da Busca é que não se acha.

Eternos mundos infinitamente,

Uns dentro de outros, sem cessar decorrem

Inúteis; Sóis, Deuses, Deus dos Deuses

Neles intercalados e perdidos

Nem a nós encontramos no infinito.

A metafísica está intimamente atrelada ao pessimismo porque prescinde da "Busca" infinita e diante do irromper das mais diversas formas elege um modelo. Estabelece que um movimento que retomasse a si mesmo sem propósito não tem o direto de ser. A alternativa adotada é a cisão da vida em âmbitos ordenados hierarquicamente tendo em vista um télos. O pessimismo, na obra de Nietzsche, aparece pela primeira vez como objeto de reflexão tendo como plano de fundo a crítica à concepção do trágico desenvolvida por Schopenhauer. Para Schopenhauer, o trágico é pensado enquanto o saber de que o mundo e a vida não proporcionam satisfação e que por isso não são dignas de apego.

O que pensava, afinal, Schopenhauer sobre a tragédia? "O que dá a todo o trágico o empuxo peculiar de elevação" - diz ele em O Mundo como Vontade e Representação, II, p. 495 - "é o surgir do conhecimento de que o mundo, a vida não podem proporcionar verdadeira satisfação e portanto não são dignos de nosso apego: nisto consiste o espírito trágico - ele conduz à resignação", quão diversamente falava Dioniso comigo. (NIETZSCHE. 2007, p. 18). 
Para Schopenhauer o espírito trágico conduz à ascese, a experiência estética é a negação da vontade que origina o sofrimento humano. O Nascimento da Tragédia pretende afastar qualquer vínculo entre experiência estética e resignação. Para Nietzsche, o elemento que caracteriza propriamente o trágico é a afirmação da vontade enquanto tensão e luta de forças entre o apolíneo e o dionisíaco.

Em sua metafísica da arte, o jovem Nietzsche parte do solo pessimista da vontade com o objetivo de oferecer uma tentativa de solução ao pessimismo. Mas como Schopenhauer é um pessimista? Nietzsche acredita que o pessimismo na filosofia de Schopenhauer não é um elemento meramente avaliativo oriundo de um estado psicológico prescindível ao conteúdo de seu pensamento. Consideramos o pessimismo como a consequência em última instância daquilo que Nietzsche chama de "interpretação moral do mundo e da existência". Ao interpretar a ausência de interesse do juízo estético kantiano como ausência ou supressão da vontade, Schopenhauer busca por meio da arte romper com o princípio de individuação abraçando um ideal ascético em detrimento à vida como condição para a objetividade. Nietzsche não pode admitir a negação da vontade se pretende superar a posição de seu mestre. No entanto, isso não significa negar o fenômeno ascético, uma vez que, tal como propõe o filósofo, a vontade é também vontade de negação e mesmo uma postura ascética, negadora da vida, só é possível a partir de determinada configuração do jogo entre Apolo e Dioniso.

Acerca do valor da existência, a arte trágica não representa uma recusa do viver, mas sua afirmação. Contudo, a afirmação da vida no mito trágico não adota uma posição otimista; é pelo pessimismo, mas não qualquer pessimismo, que desvelamos o que constitui o próprio do trágico. A tese sustentada por Nietzsche segundo a Autocrítica é que há na tragédia grega um modo de pessimismo mais radical, o "pessimismo da fortitude", que afirma a vontade ao dizer sim e confrontar-se com o doloroso e horrendo, que constitui o viver como contínuo irromper sem sentido, como jogo entre o sonho e a embriaguez.

Nietzsche prescinde de todo pressuposto epistemológico presente na filosofia de Schopenhauer. Para o filósofo tanto o conhecer como o sujeito pressuposto são configurações dessa vontade artística que se exprime como sonho e embriaguez. O cogito cartesiano nada pode fundar, pois é compreendido como um efeito. No sonho estamos "colhidos sob o véu de maia" e uma vez que não dispomos de um critério infalível para estabelecer a distinção entre o sono e a vigília, vale para o sonho aquilo que corresponde à representação na filosofia schopenhauriana. Acerca do sonho como impulso criador, Nietzsche afirma que: 
A bela aparência do mundo do sonho, em cuja produção cada ser humano é um artista consumado, constitui a precondição de toda arte plástica mas também, como veremos, de uma importante metade da poesia. Nós desfrutamos de uma compreensão imediata da figuração, todas as formas nos falam, não há nada que seja indiferente e inútil. (NIETZSCHE. 2007, p. 25).

Arquitetura e escultura são exemplos de arte apolínea na medida em que exigem a superexcitação da visão e o apelo ao sensível como mediação para o êxtase individual. No caso da estátua, o mármore é o elemento objetivamente concreto, que perde sua realidade quando confrontada com a imagem do deus, como a atribuição de um domínio onde não vigora a angústia do perecer, o terror da morte e da aniquilação. $O$ apolíneo não é a imagem retratada na pedra, mas o próprio ato de dar forma ao que corresponde a "metade importante da poesia" citada acima, referente à epopeia. Homero é um sonhador que ao divinizar a natureza lhe empresta medida, ordem e proporção. Foi em sonho que os deuses apareceram aos homens e o poeta épico recorda e preserva o sonho fixando-o em poema. O sonho é a bela máscara de ilusão que garante a manutenção da existência, na medida em que institui a forma definida e estabelece os limites e contornos da imagem. A arte apolínea manifesta também o feio e o terrível, mesmo a figura do monstruoso, que por sinal é abundante nesses mitos. O apolíneo é o processo de criação do indivíduo, que se realiza como uma experiência da medida e da consciência de si. O deus da beleza, cujos lemas são "Conhece-te a ti mesmo" e "Nada em demasia" é a imagem artística do princípio de individuação, que se pode compreender pelos predicados que o filósofo atribui a Apolo: o brilho solar e a aparência. Embora considerado uma divindade singular entre muitas outras, o mesmo impulso presente em Apolo engendra todo o panteão olímpico.

É numa relação com a poesia épica que se desenvolve outro elemento importante que se origina do impulso da conformidade: a música apolínea. "A primeira exigência de todas era que se entendesse o conteúdo da canção executada." " Nietzsche aponta a pobreza harmônica da música antiga, sua característica de acompanhamento do canto do poeta, no qual a estrutura periódica dos sons "se movia no mais estreito paralelismo com o texto" 10 e que a sonoridade apolínea "é uma arquitetura de sons, e acrescente-se ainda, de sons puramente aludidos, tais como são próprios da cítara." 11 Como uma espécie de música suporte para a narrativa épica.

\footnotetext{
${ }^{9}$ NIETZSCHE. 2010, p. 67

${ }^{10}$ Op. cit.

${ }^{11}$ Ibidem. p, 12
} 
Apolo é o brilhante, o divinatório, o resplandecente. Conceber o mundo apolíneo como luz significa criar um tipo específico de relação com o sombrio, o tenebroso da vida através da proteção pela imagem. A bela aparência apolínea é uma ocultação. Os deuses e heróis apolíneos são aparências artísticas que tornam a vida desejável, encobrindo o sofrimento pela criação de uma ilusão. Essa ilusão é o princípio de individuação. Assim, o indivíduo, essa criação luminosa e aparente, é o modo apolíneo de triunfar do sofrimento pela ocultação de seus traços. Como uma estratégia para desviarmos nosso olhar das paixões melancólicas e dos relatos pessimistas presente na sabedoria popular, como a inversão do dito de Sileno, como uma forma da vida nos seduzir a persistir vivendo.

Reza a antiga lenda que o rei Midas perseguiu na floresta, durante longo tempo, sem conseguir capturá-lo, o sábio Sileno, o companheiro de Dioniso. Quando, por fim, ele veio a cair em suas mãos, perguntou-lhe o rei qual dentre as coisas era a melhor e a mais preferível para o homem. Obstinado e imóvel, o demônio calava-se; até que, forçado pelo rei, prorrompeu-se finalmente, por entre um riso amarelo, nestas palavras: - Estirpe miserável e efêmera, filhos do acaso e do tormento! Por que me obrigas a dizer-te o que seria para ti mais salutar não ouvir? O melhor de tudo é para ti inteiramente inatingível: não ter nascido, não ser, nada ser. Depois disso, porém, o melhor para ti é logo morrer. (NIETZSCHE. 2007, p. 33).

Assim, para Nietzsche, nos aproximamos do fundamento sobre o qual a cultura apolínea se estabelece: a partir de uma sabedoria do sofrimento, daquele que experimentou o horror da existência e que teve que colocar entre a verdade e si mesmo uma ilusão, a resplandecente criação onírica. Criação onírica apolínea, representada no mito pela figura do rei Midas, que obriga Sileno a comunicar sua indigesta sabedoria, como representação de Apolo em seu esforço contínuo de dar forma aquilo que é em si mesmo ausência de determinação.

Para Nietzsche, a sabedoria de Sileno é a raiz sobre a qual se ergue o Monte Olimpo, como inversão e mascaramento dos horrores da existência, como um tranquilizador que torna a vida possível operando, numa linguagem mítica, a transição da primitiva teogonia dos terrores titânicos à teogonia olímpica. Vale ressaltar o abismo que separa o Dioníso da tragédia ática do Dioníso bárbaro, cuja natureza titânica consiste na pura aniquilação. Celebrado nas festas dionisíacas presentes em todos os confins do mundo antigo, de Roma à Babilônia caracterizadas pela desenfreada licença sexual e ruptura com as convenções sociais, numa mistura de volúpia e crueldade do qual os gregos se protegeram durante algum tempo pela influência magistral do elemento ordenador. Apolo se caracteriza por esse momento de rejeição ao dionisíaco bárbaro 
que aparece sob a figura do sátiro, se colocando diante do olhar petrificador da Medusa, àquela verdade paralisante do poder ameaçador do elemento dionisíaco brutalmente grotesco.

Onde quer que deparemos com o "ingênuo" na arte, cumpre-nos reconhecer o supremo efeito da cultura apolínea: a qual precisa sempre derrubar primeiro um reino de Titãs, matar monstros e, mediante poderosas alucinações e jubilosas ilusões, fazer-se vitoriosa sobre uma horrível profundeza da consideração do mundo [Weltbetrachtung] e sobre a mais excitável aptidão para o sofrimento. (NIETZSCHE. 2007, p.35).

De acordo com Nietzsche, os gregos não estavam isentos da cisão entre ser e parecer. O mundo clássico das formas definidas, que Nietzsche chama cultura apolínea, que permitiu ao grego produzir um mundo de beleza e de compostura como é o caso das divindades olímpicas e da literatura trágica, como vivos exemplos de uma humanidade serena e equilibrada, desconhecedora de conflitos só se sustenta numa relação com sua experiência fundamental da dor. Concordando com Vattimo ${ }^{12}$, não se trata de suprimir a aparência como um retorno à unidade primordial, mas de reencontrar o dionisíaco como livre energia poetante, além do medo e da insegurança que o faz decair em produção de disfarces encobridores. Apolo mascara a essência dionisíaca do mundo, através de uma ficção que permite nos esquecer dela por um instante, glorificando nos deuses olímpicos o mundo da existência cotidiana, nos tornando mais dispostos a aceitá-lo como é. Trata-se do elogio da aparência que se torna sinônimo de mundo de liberdade e eliminação de barreiras sociais.

Vattimo utiliza o conceito máscara para abranger as múltiplas formas da criação artística na obra de Nietzsche. Em O Nascimento da Tragédia a máscara surge a partir da experiência fundamental dos sofrimentos próprios do Uno-primordial da vontade $^{13}$. Que concorda com a ideia anti-hegeliana da impossibilidade de uma perfeita coincidência entre ser e parecer, que está na base da filosofia schopenhauriana que aponta para uma recusa do racionalismo metafísico como lugar comum na filosofia de Nietzsche: "A dor e o sofrimento não passam de maneiras de apontar a não unidade originária do princípio primordial das coisas, a duplicidade insuprimível do ser". ${ }^{14}$ Com efeito, se para Schopenhauer ainda é possível libertar-se da corrente da aparência por meio da ascese, para Nietzsche a inevitável divergência entre ser e parecer, entre fenômeno e coisa em si, é mais fundamental. Podendo até mesmo dar ensejo à criação de um modelo ilusório onde essa adequação que realiza a coincidência entre

\footnotetext{
12 VATTIMO. 2017, p. 42

${ }^{13}$ Ibidem. p, 25

14 Ibidem. p, 37
} 
os dois modos de ser seria possível, ou seja, como ficção que cria uma imagem de totalidade que nos aproxima do sonho patológico, que se esqueceu como sonho e quer valer como realidade.

Ao revisitar sua obra de juventude, Nietzsche nos fragmentos póstumos chama atenção para o caráter aterrador do fenômeno dionisíaco como esta propensão intelectual para o duro, horrendo, mal e problemático da existência. Para o filósofo "que o caráter da existência seja desconhecido - eis o mais profundo e elevado intento secreto por trás de tudo que é virtude, ciência, piedade e criação artística." ${ }^{\text {"15. }}$

Vê-se que neste livro o pessimismo, falemos mais claramente: o niilismo, vale como a verdade. Mas a verdade não vale como a mais elevada medida de valor, menos ainda como poder supremo.A vontade de aparência, de ilusão, de ludibrio, de devir e mudança (de ludibrio objetivo) vale aqui como mais profunda, mais originária e mais metafísica do que a vontade de verdade, de realidade, de ser: - esta última é apenas uma forma da vontade de ilusão. (NIETZSCHE. 2008. p, 427).

O dionisíaco chama atenção para o caráter fundamental da dor enquanto elemento constitutivo do existir. Pertence ao elemento dionisíaco a superação dos abismos que separam homens e natureza, gerando um sentimento de unidade que experimentamos como embriaguez. O dionisíaco está numa esfera de forças que exprime o caos e a dor do mundo contida no Unoprimordial, expressão do núcleo do qual tudo emana, como o "verdadeiramente existente". Essa descomunal potência geradora que foi mascarada pela civilização apolínea com intuito de conter seu poder destrutivo e sua violência natural. O que Nietzsche afirma, entretanto, é que a aparência é um movimento próprio do dionisíaco para "purgar" o seu sofrimento, para se redimir na aparência. Para Nietzsche, que discorda da metafísica tradicional, não faz sentido alimentar aversão à aparência como estando sob o signo do falso e do não confiável, do nãoverdadeiro. A expressão desta dor primordial na aparência faz surgir a música enquanto força simbólica, gesto e ímpeto na harmonia que brota diretamente do seio da dor do deus dilacerado, do grito da natureza que, em seu ciclo infinito, se cria e se destrói para se recriar. Dioniso representa esse fenômeno da vontade criadora, no qual "para que haja criação constante, para que haja vida, é preciso que a forma se desfaça, não dure infinitamente, e que o movimento de

${ }^{15}$ NIETZSCHE. 2008, p. 426 
vir à forma não cesse jamais." 16 A arte trágica torna-se uma segunda moldagem da natureza capaz de nos colocar diante de seu movimento originário de devir.

O artista primordial Dionísio é compelido a criar a realidade do belo mundo apolíneo, ao diferenciar-se de si mesmo, despedaçando-se na multiplicidade. Do mesmo modo os mais insignes exemplares do homem precisam ser aniquilados, retribuindo o favor do despedaçamento de Dionísio, restituindo, no ocultamento, o amor ao surgimento, à aparência. Apolo e Dionísio dão-se as mãos, pois um ama o outro, concedendo cada um ao outro aquilo que o outro é. (CORDEIRO, 2017, 102-113).

O dionisíaco é o afeto que se refere à linguagem musical e se relaciona com um universo oposto a ela, a imaginação figurativa, configurando a realidade da obra de arte trágica. Para exprimir simbolicamente essa realidade, porém, é necessário que o homem abandone sua subjetividade e se deixe encantar pela natureza. O entusiasmo é a marca principal do servidor ditirâmbico de Dioniso e é entre si, agrupado nos bandos do coro satírico, que esse transe se propaga. No Crepúsculo dos Ídolos, em um fragmento chamado "Da Psicologia do Artista", Nietzsche assim se expressa a respeito do artista dionisíaco: "Para que exista arte, para que exista algum fazer e contemplar estético, é imprescindível uma condição fisiológica: a embriaguez. A embriaguez precisa inicialmente ter intensificado a excitabilidade da máquina inteira: antes disso não se chega à arte alguma." Absortos e fora de si, os servidores dionisíacos agem como se estivessem transformados, como se não fossem mais cidadãos nominais de tal cidade ou polis, mas sim encarnado forças da natureza, emitindo sons, cantando, dançando. Aqui observamos que a música dionisíaca toma uma proporção diferente da música apolínea:

Da mais elevada alegria soa o grito de horror ou o lamento por uma perda irreparável. Naqueles festivais gregos prorrompia como que um traço sentimental da natureza, como se soluçasse por seu despedaçamento em indivíduos. O cântico e a mímica desses entusiastas de tão dúplice disposição eram, para o mundo Greco-homérico, algo de novo e inaudito: a música dionisíca, em particular, excitava nele espantos e pavores. (NIETZSCHE. 2007, p. 31).

O surgimento do "incomparável mundo da harmonia", o caráter reveladoramente violento e despótico da natureza do som em relação ao mais profundo dentro do homem, a mímica aliada às palavras, tudo isso intensificou as capacidades simbólicas humanas e permitiu com que a tragédia ática fosse possível. Segundo Roberto Machado ${ }^{17}$ tal intensificação

\footnotetext{
${ }^{16}$ DIAS, R. M. 2011, p.82

${ }^{17}$ MACHADO, R. 2006
} 
simbólica possibilitou com que a aliança fraterna do dionisíaco com o apolíneo constituísse a gênese da tragédia enquanto unificação de "por um lado, a música, por outro, a cena e a palavra”. Sobre essa dupla origem da tragédia grega:

Em oposição a todos aqueles que se empenham em derivar as artes de um princípio único, tomando como fonte necessária a toda obra de arte, detenho o olhar naquelas duas divindades artísticas dos gregos, Apolo e Dioniso, e reconheço neles os representantes vivos e evidentes de dois mundos artísticos diferentes em sua essência mais funda e em suas metas mais altas. Vejo Apolo diante de mim como o gênio transfigurador do principium individuationis, único através do qual se pode alcançar a verdade a redenção na aparência, ao passo que, sob o grito de júbilo místico de Dioniso, é rompido o feitiço da individuação e fica franqueado o caminho para as Mães do Ser, para o cerne mais íntimo das coisas. Essa imensa oposição que se abre abismal entre aparência plástica, como arte apolínea, e a música, como arte dionisíaca, se tornou manifesta a apenas um dos grandes pensadores, na medida em que ele, mesmo sem esse guia do simbolismo dos deuses helênicos, reconheceu à música um caráter e uma origem diversos dos de todas as outras artes, porque ela não é, como as demais, reflexo [Abbild] do fenômeno, porém reflexo imediato da vontade mesma. (NIETZSCHE. 2007, p. 94).

Tal duplicidade pôde ser temporariamente resumida neste acordo de paz com o surgimento da tragédia, uma obra de arte que unificou as pulsões tanto apolíneas quanto dionisíacas. A reconciliação dos dois impulsos levou Nietzsche a reconhecer que se operou uma transformação de um "fenômeno natural" em um "fenômeno artístico" e, por isso ainda nesse primeiro momento, metafísico. O resgate empreendido por Apolo para retirar as armas das mãos de Dioniso e transformar a sua selvageria titânica, bárbara, em poesia, cena e música, em um saber artístico de profundidade trágica.

A hipótese que sustenta a base da ideia de Nietzsche é de que o coro trágico foi iniciado a partir do desenvolvimento apolíneo da turba satírica. Aqui, é importante lembrar o que Machado nos disse quanto ás formas estéticas criticadas por Nietzsche e que viabilizaram essa perspectiva: "a primeira forma rejeitada é possivelmente de Hegel que defendia na estética que o coro grego representava a sabedoria do povo, exprimia os pensamentos e os sentimentos coletivos em contraposição ao discurso individual". Outra via rejeitada foi a de AugustWilhelm Schlegel "que vê o coro trágico como a substância e o extrato da multidão de espectadores ${ }^{18}$ ". Nesse ponto seria impossível tirar do público, por idealização, o coro trágico, uma vez que o espectador tem consciência de que vê um espetáculo enquanto que o coro vê na cena figuras reais, o padecimento do próprio deus. No entanto Nietzsche elogia a interpretação

${ }^{18}$ MACHADO, R. 2006. 
de Schiller que vê no coro "uma muralha viva que a tragédia estende à sua volta a fim de se isolar totalmente do mundo real e de salvaguardar para si o seu chão ideal e sua liberdade poética ${ }^{19} "$. O coro trágico é, na visão de Nietzsche, a imitação artística do cortejo embriagado e exaltado ao deus Dionísio, visto em cena pelos servos do deus, transfigurados, experienciando a dor do despedaçamento e o júbilo do retorno ao fundo da natureza.

Nietzsche legitima ainda mais o discurso de Schiller sobre o poetar também quando este diz que "ter tido ante si e em si, como condição preparatória para o ato de poetar" o estado de ânimo musical e não uma "série de imagens ordenadas" pela causalidade do pensamento. Aqui, então se reconhece uma implicação ou raiz comum, uma identidade, de um tipo de linguagem e expressão: a poesia e a música como expressão do sentimento, ou, em linguagem schopenhauriana, da vontade ${ }^{20}$.

Ele se fez primeiro, enquanto artista dionisíaco, totalmente um só com o Unoprimordial, com sua dor e contradição, e produz a réplica desse Unoprimordial em forma de música, ainda que esta seja, de outro modo, denominada com justiça de repetição do mundo e segunda moldagem deste: agora porém esta música se lhe torna visível, como numa imagem similiforme do sonho, sob a influência apolínea do sonho. (NIETZSCHE. 2007, p. 41).

Assim, o poeta lírico não seria subjetivo. Antes teria renunciado à sua subjetividade, às suas emoções particulares, para expressar o sofrimento e o júbilo do Uno-primordial. A natureza do artista dionisíaco fica marcadamente nítida em relação ao artista apolíneo. Enquanto o artista plástico e épico está mergulhado na pura contemplação das imagens, o dionisíaco - isento de imagens, é ele próprio dor primordial e eco desta. Assim "o gênio lírico sente brotar, da mística autoalienação e estado de unidade, um mundo de imagens e de símiles, que tem coloração, causalidade e velocidade completamente diversas do mundo do artista plástico. ${ }^{21}$ " Por isso também que não se ocupam do mesmo meio e não utilizam a mesma linguagem, um joga com o sonho, o outro com a embriaguez como precondição para o ato estético, embora ambas tenham se complementado na natureza do artista trágico, que joga simultaneamente com o sonho e com a embriaguez.

Como teria acontecido, de acordo com Nietzsche, essa transição da turba satírica para o coro trágico? A ligação se dá, sobretudo a partir da figura do sátiro. "Segundo Nietzsche, o sátiro, ser natural fictício, fingido, era para o grego uma autêntica verdade da natureza, 'a

\footnotetext{
${ }^{19}$ NIETZSCHE. 2007. p. 51

${ }^{20}$ Ibidem. p, 41

${ }^{21}$ NIETZSCHE. 2007, p.42
} 
natureza intocada pelo conhecimento', 'a imagem e o reflexo da natureza em seus impulsos mais fortes', 'o anunciador da sabedoria que sai do âmago mais profundo da natureza', 'a protoimagem do homem" "22. É pela imitação dos seres naturais, feita pelos sátiros, que a cena se move e é constituída, é que se começou a aparecer as personas e personagens que criaram a cena trágica, ampliando a comunicação da realidade trágica na linguagem gestual, conjugada com a música extática e o coro.

Enquanto imitador da natureza o artista trágico é um transfigurador que não busca “imitar" uma realidade fenomênica, mas sim a exprimir e imitar a realidade íntima da natureza, sua essência, sua vontade. Desta forma a arte trágica se torna um suplemento metafísico da realidade, uma tradução artística da própria natureza. Na tragédia o herói torna-se exemplar, despertando o sentimento trágico naquele que reconhece diante de si seu ser e sua impotência diante do destino. Não se trata de uma justiça que se abate sobre um indivíduo culpado, mas sim de uma ordem metafísica do ser válida para todos, imitação de uma verdade comum que vincula também o poeta. A música seria a imitação do instinto dionisíaco da natureza e é a partir da possibilidade de sua linguagem no mundo humano que a tragédia teve sua origem.

Sob a sanção do mito e do culto, o coro ditirâmbico participava, por alguns momentos, da realidade atroz e absurda que subsiste por trás de toda individuação, aclarados e trazidos ao transe extático pelo poder arrebatador da música. O poder de possessão - ou embriaguez torna-se pré-condição para a arte dramática. Enfeitiçados, os participantes do coro de sátiros entra num mundo de visões tornadas possíveis pela excitação dionisíaca. Para, no entanto, tornar o drama completo, se faz necessário o elemento visível, que o apolíneo dê forma ao informe dionisíaco que provoca o drama.

A música por si só pode ser compreendida enquanto linguagem do pathos, mas nunca como origem do drama de forma isolada. O coro é apenas o protofenômeno ${ }^{23}$ dramático. $\mathrm{O}$ seguidor bacante, em seu encantamento musical, "vê a si mesmo como sátiro, e como sátiro por sua vez contempla o seu deus", isto é, em sua metamorfose ele vê fora de si uma nova visão, que é a ultimação apolínea de sua condição. Com essa nova visão o drama está completo ${ }^{24}$. Numa alusão à tragédia de Sófocles:

Em Édipo em Colono nos deparamos com essa serenojovialidade, porém elevada a uma transfiguração infinita; em face do velho, atingido pelo excesso

\footnotetext{
22 MACHADO, R. 2006.

${ }^{23}$ NIETZSCHE. 2007. p, 58-59

${ }^{24}$ Op. Cit.
} 
de desgraça, que, a tudo quanto lhe advém, é abandonado como puro sofredor - ergue-se a serenojovialidade sobreterrena, que baixa das esferas divinas e nos dá a entender que o herói, em seu comportamento puramente passivo, alcança sua suprema atividade, que se estende muito além de sua vida, enquanto que a sua busca e empenho consciente apenas o conduziram à passividade. (NIETZSCHE. 2007, p. 61).

A tragédia é esse coro dionisíaco que incessantemente se descarrega em um mundo “serenojovial”, apolíneo, de imagens. A emoção abundantemente proporcionada pelo estado de ânimo musical evoca espontaneamente na imaginação do coreuta representações visuais. A ação dramática da tragédia seria essa projeção em cena das imagens de sonho com formas bem delineadas, mas exteriorizando a potência musical, o estado de espírito provocado pela música. O drama está realmente completo quando entra em cena o ator que representa a figura vislumbrada pelo coro, Édipo é imagem para o disforme deus Dioniso, pois se trata dos sofrimentos dele, de seu martírio e renascimento no eterno fundo da natureza. Todas as figuras afamadas do palco grego, Prometeu, Édipo e assim por diante, são máscaras daquele protoherói, Dionísio.

O Prometeu acorrentado de Ésquilo nos oferece outro exemplo de transfiguração da dor em imagens. Chamado de hino da impiedade, o artista titânico ou dionisíaco encontra em si a crença de poder criar seres humanos e aniquilar deuses olímpicos. Se a arte apolínea da epopeia representa a vitória do Olimpo sobre a estirpe titânica, o drama trágico representa o magnífico poder do artista humano que pressente um crepúsculo dos deuses, compelindo os dois mundos do sofrimento à unificação metafísica que confere dignidade ao sacrilégio.

O altivo titã Prometeu avisou a seu torturador olímpico que a sua soberania estava ameaçada pelo maior dos perigos, a menos que se aliasse a ele no devido tempo. Em Ésquilo reconhecemos a aliança do aterrorizado Zeus, temeroso de seu fim, e o titã. Assim, a antiga era titânica é posteriormente de novo retirada do Tártaro e trazida à luz. (NIETZSCHE. 2007, p. 68).

Tanto em Édipo, quanto em Prometeu, pode-se ler a ruptura das barreiras e dos tabus familiares e sociais nos quais se fundamenta o mundo apolíneo da forma. Prometeu significa a rebelião contra a paternidade divina, mais elevada que a natural contra a qual Édipo se insurge. Enquanto Édipo evidencia o dionisíaco como supressão da ordem familiar, o mito de Prometeu acentua o poder de submeter também a natureza divina, violada com o furto do fogo e cujo sofrimento do herói é o tributo da aniquilação que copertence e integra o poder criar que constitui o artista que somos. 


\section{REFERÊNCIAS BIBLIOGRÁFICAS}

CORDEIRO. R. C. Nietzsche a filosofia do trágico. Revista: Eleuthería. Campo grande, MS. v. 2, n.2. p, 102-113. 2017.

DIAS, R. M. A Influência de Schopenhauer na Filosofia da Arte de Nietzsche em O Nascimento da Tragédia. In: cadernos Nietzsche 3, p. 07-21, 1997.

. Nietzsche, vida como obra de arte. $1^{\mathrm{a}}$ ed. Rio de Janeiro: Civilização Brasileira, 2011.

PESSOA. F. Primeiro Fausto. Disponível em: < http://www.dominiopublico.gov.br/download/texto/pe000005.pdf> Acesso em: 02 de Jul. 2020. HEIDEGGER. Nietzsche. Trad. Marco Antônio Casanova. Rio de Janeiro: Forense Universitária, 2010.

MACHADO, R. Nietzsche e a verdade. $1^{\text {a }}$ Ed. Rio de janeiro: Editora Rocco, 1984. Nietzsche e a representação do dionisíaco. In: O nascimento do trágico: de Schiller a Nietzsche. Rio de Janeiro: Jorge Zahar Ed., 2006.

Zaratustra: Tragédia nietzscheana. $4^{\mathrm{a}}$ ed. Rio de Janeiro: Zahar, 2011.

NIETZSCHE. O Nascimento da Tragédia ou Helenismo e Pessimismo. Trad. J. Guinsburg.2 ${ }^{\mathrm{a}}$ Ed. $7^{\mathrm{a}}$ reimpressão. São Paulo: Companhia das letras, 2003

. A Vontade de Poder. Trad. Marcos Sinésio Pereira Fernandes; Francisco José Dias de Moraes. 2008. . A Visão Dionisíaca do Mundo. Trad. Marcos Sinésio Pereira Fernandes, Maria

Cristina dos Santos Souza. $1^{\mathrm{a}}$ Ed. $2^{\mathrm{a}}$ tiragem. São Paulo: Martins Fontes, 2010.

SCHOPENHAUER, A. O Mundo como Vontade e Representação. Trad. Jair Barbosa, São Paulo; Editora UNESP, 2005.

STEGMAIER, W. A Filosofia da Arte de Friedrich Nietzsche. In: As Linhas Fundamentais do Pensamento de Nietzsche; Coletânea de artigos 1985-2009. Org. Jorge Luiz Viesenteiner e Andre Luiz Muniz Garcia - Petrópolis, RJ: Vozes, 2013. 


\section{Revista \\ $\triangle P O E N A$

VATTIMO, G. Diálogo com Nietzsche: ensaios de 1961-2000. Trad. Silvana Cobucci Leite. $1^{a}$ ed. São Paulo: Martins Fontes, 2010.

O Sujeito e a Máscara: Nietzsche e o Problema da Libertação. Trad. Silvana Cobucci Leite. Petrópolis, RJ: Vozes, 2017.

Artigo recebido em: 02/07/2020

Artigo aprovado em: 09/09/2020 